\title{
Reading and Accounts
}

1

$\mathrm{I}$

work every day in the Cornell College Library. Usually on the ground floor level, where the fast computers are. The other day I took an early afternoon break, and went up to the second floor reading room to get a copy of The Times and relax. As I passed through the reading room I saw a Japanese student sitting at the long reading table, studying his physics text. He was sitting up straight; the hard back book was standing vertical in front of him on the table, three feet away. The room was pretty silent and the boy was concentrating. I got my paper and took it back to the lower level to read.

I read for twenty minutes, then returned to my computer, where I worked for an hour and a half. I finished my online teaching for the day, I packed up my stuff, climbed back up the stairs to the reading room, crossed the room to exit. At that point, tired and stretching, I usually don't observe much. But this time I noticed the same Japanese student. He was still in the same position, sitting upright looking at his book, balancing it firmly in both hands. He seemed still to be in the same position of attention: nothing had changed, I felt, except the design on the page: a different graph of a different color. I went out through the main door of the Library, and went home.

2

The Japanese student, I think, was reading. (He may simply have been sitting idly, staring at the black marks on white, and flipping the pages from time to time. The chances are against that.) His back was straight, his attention focused. In fact he was so intent that you had to wonder what kind of ritual act he was performing. It looked like he was reading, but then how do you read? Do you first break the normal flow of the body? Do you bend yourself? How do you make a body sit down and do that? Is this the same body that in prehistoric times went out to do battle with a mountain lion and bring home dinner? Is that supple body ready for everything? If so, how comes it that that same body is now vertical from the waist, staring at words on a page?

3

I walk around the track with John, a local Professor. It's about 8:15 and I'm getting hungry for my nine o'clock breakfast. John's already eaten, and 
taken his kids to school. He's on sabbatical, so has some free study time, and is pursuing a research project on Pausanias. We talk about that a little, exchange observations on the current political campaign, then come to the end of our eight circuits. Time to part. In the last fifty yards I ask him what he's 'going to do today?' He says 'read, read on in Pausanias.' That hits me. Read on? Read? How do you do that? What's the first thing John's going to do when he's fixed his coffee? In a split second I imagine the answer to my 'how do you do that' question. He's going to do something like this. He's going to walk with his coffee toward some armchair in the living room-I imagine his house like mine, though I have never been in it—he's going to put his feet up, so the blood doesn't rush to his feet, he's going to take a hard backed book from the coffee table beside him; then he's going to 'read,' as the Japanese student did. John is going to hold the book in front of him and look at it, and do that and more for a while. Probably no one realizes he's there. Maybe his wife is the one who's going to come in the room later and see him and think 'he's doing the same thing he was doing two hours ago.' She may notice, if she is inclined, that the number in the upper right hand corner of his book has changed. It was seventy five. Now it's eighty three. Is that how you read? You change the numbers on the pages? She's a reader too, though, and doesn't give it a lot of thought. She knows what he's doing. What he's doing seems to her natural.

\section{4}

So how do you read? What were John and the Japanese student doing during the elapsed times we reviewed? We all know in a way what they've been doing, and what that means they have not been doing. We can start at either point. The two readers have not been killing mountain lions or planting cassava. (Other people can do those things for them.) Their personal value ambitions incline them toward 'reading.' They have been feeding their eyes on black symbols against white pages, then turning those pages when they finished reading the page they were on. They have made some gentle physical motions. What else have they been doing?

As usually true in such situations, the best start is to ask the participants directly: What have you been doing? In the present case, it is not too easy to ask that question. I probably cannot locate the Japanese student, and John is not likely to want, even if he can, to spend much time answering that question. So let me guess. The Japanese student replies that he learned how the properties of elasticity can be reduced to mathematical formulae. If he and $\mathrm{I}$ are both somewhat informed on that topic, he may recount in more detail what he feels he has learned from his reading. John will probably let me know something like this: that he has learned certain peculiarities of the Argive Heraeum in the days of Pausanias' visit to it. I will in both cases-if they ever take place-go away with a resume of the two guys' responses.

When I think about their responses later, I am likely to ask myself what connection there is, between their responses and the certain number of 


\section{READING AND ACCOUNTS}

hours they spent in reading, readying themselves to give those responses. I mean that in two ways. The first is obvious. When they were reading, the two guys were silent, and their eyes were digesting symbols in an acquisitive pattern proper to the action of the learning human eye. That specialized action is different from the statements the two guys made, about what they had learned in their reading. Those are different things, that act and this account. That's the first thing I meant. I also mean to draw attention to another kind of difference between the reading act and the account of it. This is a subtler difference. Let's say we remove, from the account of what 'reading' is, the physical symptoms of it, and concentrate on the intellective grasp of patterns of meaningful symbols. Will looking at what John was doing, in his reading, be in this case more germane, than in the previous example, to the account he gives of what he was doing? Won't we in this second case be left thinking that what John says about his reading is an awfully brief summary of what he must have 'intellected' from those symbols that day? Mustn't we feel that John's summary of his reading act is prima facie improbable? Aren't we still left asking what reading is, and more deeply, how we read? Can we even get to the reality of what John was doing in reading? Is the negative answer we must reply simply an aspect of the inevitable distance between doing something and giving an account of what you were doing? Or is it a problem specific to questions about reading? Can asking John and the Japanese student what they were doing in reading never make any sense?

\section{5}

We are on a theoretical issue here. It was not my intention to block; to block real discourse about what these guys were doing when they were reading; to block discourse into how we read, all of us in general who do the action. But it seemed best to face the facts, from the outset. Getting an answer to our question of what reading is not easy. Squaring John's or the student's accounts of what they were reading, with what they were in fact doing, is not getting easier.

We've got John and the Japanese student in chairs holding books; we've seen evidence of pages turned; we've even asked the two what they were doing when they were reading, and gotten answers which, if genuine, seem implausible accounts of what the two were doing in reading. We are not certain that the accounts are implausible. It is possible that in the course of his reading John was essentially repeating over and over to himself a summative phrase about the Argive Heraeum, and the Japanese guy a similar kind of phrase about formulae of elasticity. However the introspection available to me, as I write this about reading, suggests that the answer to how we read can't be reduced to summative observations we might make, about 'what we read.'

How can I recreate the experience of reading? Is it easier for me, through introspection, to explain the reading process to myself, than it was for John or the Japanese guy to explain the reading process through narration? My guess is, yes and no. When I ask John to tell me what he was doing, reading, he 
has a formal assignment and discharges it briskly, as we have seen. He knows how to answer what I am asking him. He goes for the conceptual formulation heart of the matter, and lays a brick of an answer before me. I would do the same for him if he asked me about what $I$ was reading. When I ask myself about what I've been reading, Mission to Asia: Franciscan Missions in Mongolia and China in the Thirteenth and Fourteenth Centuries - I can either come up with a summative response, 'a book about the impact of the Mongol and Tartar world on some papal messengers from the West'-or with a murky inner fumbling, in which I offer flashes of the drama of consciousness that has preoccupied my reading of Mission to Asia. In that latter kind of replying I will, say, give prominence to certain blocks of consciousness-wintry survival of the missionaries on the plains of Central Asia; encounter of the missionaries with heavily armed warriors in a mountain pass-but those blocks are vulnerable shreds in the mind's landscape. As John will discover, in listening to my response, I will also 'feel' close to the texture of the work I have been going through, perhaps in that way overlapping the consciousness of the writer of the work, though just what that overlapping could mean is a long story. I will be both close to the work I have just been reading, and distinctively unable to characterize what I have been reading.

\section{6}

In asking 'How do you read?' I am asking what takes place in the course of reading. The answers I get to this question from others-John, the Japanese student - are implausible accounts of what takes place in that reading act to which time spent, bent body posture, fixed eyes testify. What I was able to offer, from my own introspection about my reading, was little improvement on my friends' efforts. I may have tapped a certain intimacy, to the feel of the reading act, which eluded the summaries offered by my friends. But in so doing I sacrificed my power to seize the reading experience in a conceptual grasp. I was left with either chitchat or a sterile formula in response to the question what I was doing in reading.

So how do you read? Does the answer to this question require inspecting a broader relationship familiar to us from other points in our lives, thus perhaps more familiar to us than we might have expected?

Accounting for events or activities is the broad relationship category in question here. It is something we do all the time, so that accounting for what we do when we read is just a sub category of this larger field of accounting. When you get home from class your Mom asks: How did you do in math today? When you take your Ph.D. orals your senior professor asks you how you found the reading of Andler's huge book on Nietzsche. When you have your first serious scrape with death, the attending physician asks how you managed to hold on until the rescuers found you, and pulled the ton of rubbish off you. Accounting for how you did something - effected the math test, got through the Andler, or survived the almost breathless waiting under rubble-is 


\section{READING AND ACCOUNTS}

a most familiar exercise and is invariably futile. The account always fumbles before the job of reporting the actuality of the event.

Is this impotence in accounts simply a factor of the way nothing in our lives is identical to anything else, and especially of the way intellection can never equal its object? Yes, and yes in spades for intellection, which so clearly exists as difference — of thought from thing or condition — that we might want to say that intellection is nothing more than the fine point on difference. Without the advent of consciousness, into the sphere of created things, there would arguably be nothing like difference. What-is would be a continuum of presence. The quantum leap of awareness, given to human beings by consciousness, exacts a generic revenge: in an advanced animal of our sort the penalty for thinking is immersion in difference from what you think or talk about. That brief summary, of the evolutionary history of consciousness, is a hint at the folly of trying to explain what reading is or was.

But are we invoking a perspective too wide to be of detailed interest to the case (say) of accounting for how we read? After all, accounting also has to explain why we have to learn how to tie our shoes, when we're toddlers, and ever after, throughout life, how we have to at least reinvoke our primal skills at lacing and bow tying. Accounting is an accounting for any and every thing. Are we invoking a perspective based on the fact that temporal development is by nature an unfolding of difference, so that nothing can be identical to anything else? We are invoking that panoramic perspective, which cuts to the heart of ontology, and in that sense we are swamping the particular query about 'how we read.' But we are shortcircuiting the fine texture of our whole query, by sidestepping the contextual spotlight appropriate to the reading act itself, which is if nothing else, and if susceptible to no other account, par excellence the place within consciousness where the condition of difference is most vividly highlighted.

John, the Japanese student, and I would in time, and predictably, have added, to our fumbling accounts of what reading is, of how we read, indications that reading highlights the mystery of concentration, and is in a sense a ritual church of its own; bending the body, bending the mind to a set of formulaic actions. It is in that context that I have stressed the posture of the Japanese student, John's imagined feet-up eyes-fixed regimen of reading, and my own sense of a special realm, occupied in reading, which I can't effectively describe 'from this side' of the action.

Within the ritual of the reading action, a phenomenology of intense and then unfocused attentions takes place. There are curves of attentiveness, phases of synthesis, new-challenge acceptances, and even stupors. For all that we cannot say of the reading act, and for our own difference from it, there is much we can say of it. One thing is that the reading act is a landscape of its own, colorful and shifting, drearily down, or fretted with every desire we can bring to bear on it. Perhaps the best way to characterize reading, after all, is to characterize the writing we do to create the material of reading. That writing is the inside of the single fabric, reading, and by serving as reading's obverse can 
tell us something essential abut what reading is. Will we not widen our sense of reading's 'difference,' by this reverse probe?

\section{7}

I don't know how to account for what reading is, and I suspect that failure to account may be kin to the human problem of 'accounting,' the notorious difficulty of which rests on our existential condition, forward surging entities failing by nature to acquire a post from which to look back on a stable object of knowledge in our past. This landscape of unremitting distance is one in which the closure of beholder with object is swallowed in flux. The 'unreality of tense,' the deceptive illusion of time itself, may seem to open a corner for Platonic meaning, for the moment in the rose garden. But such insights play no role in the palette of transitions which make up the fresco of reading.

The writing act is unseen in the reading act, but must inevitably share traits with its sister action. To write is to parcel out the segments of a script, pen or keystrokes grumpily lagging behind intention. To write is to make movements with your hands-your voice may be sufficient in the computers of the future-and through them to impart signs to whatever-page, stone, screen-can retain the imprint. To be the writer is to get your symbol intelligence directed through language (or mathematical symbols) onto that carrier page or screen. That's what being a writer is, and it's that raw action that provokes the reading act over against it. The reading act may be different from the writing which is its obverse; from the writing down of 'The Story of Sinuhe' to my reading of it this morning is an obverse stretched thin by the (illusory) passage of time. How we write is covered by such physical descriptions, in the sense that how we read was covered by descriptions of John's behavior in his chair, or the posture of the Japanese student.

How about the inside of the writing effort? Does it resemble that landscape of gaps, focus points, eye floaters and somnolence which we traverse in reading? The cliché holds that writing is the more active act, reading the more passive. I prefer seeing the two acts as one, for that is what the acts' mutual obverseness suggests. The two acts might be called 'two things you can do in a chair,' each done by the same person, and at the same time. It is as though the writer writes by being at the same time his own reader; while the reader reads by being at the same time his own writer.

\section{8}

Reading and writing are critical human commitments, arguably related to many of our advanced skills. Do we know enough, about what reading and writing are, to see why those advanced skills rely on reading and writing? We may not know enough, particularly given how hard it is to know what reading and writing are. (Quantitatively, we may fill in many empirical details, to convince ourselves we know what reading and writing are. We can measure eye movement patterns in reading; measure children's differential rates for 


\section{READING AND ACCOUNTS}

learning to interpret written symbols; we can even scan the brain of the 'great writer' in action, to see what distinctive patterns are mobilized by that muscle. But from this quantitative assemblage to an account of the reading or writing act is as far as from a biological inventory of an individual, to naming what that person is.) We may not know enough, may not be in a position to know enough, to explain why reading and writing are essential to our advanced skills.

Is such an assertion, of such an essential relation-between reading/writing and advanced skills_-then so much mouthwash? Must it fall victim, under scrutiny, to the ban on accounts?

The evidence we can give, of the advanced skill relatedness of reading and writing, can only derive from 'doing the answer.' Just as expressing what reading or writing are comes down to reading or writing; and thus to the larger theme of this essay, that explanation in general is only doing. And what about giving accounts of giving accounts of reading and writing? Are those twice removed accounts not additional proof that explanation has always already taken place?

School of Advanced Studies, University of Phoenix, United States 